青刈りトウモロコシで飼養した牛乳の揮発性成分

上隆保・大崎和彦*

広島大学生物生産学部, 福山市 720

*稻畑香料株式会社, 大阪市 532

(1986. 6. 2 受付)

\begin{abstract}
要 約 飼料作物と牛乳フレーバーとの関係を調べる目的で, 青犾りトゥモロコシとそれで飼養した 乳牛の牛乳の揮発性成分を, ガスクロマトグラフ・マススペクトロメーター执ざ水素炎イオン化検出 器のガスクロマトグラフによって分析した。 また各成分の面積\%および ppb 濃度は，へプタデカンを

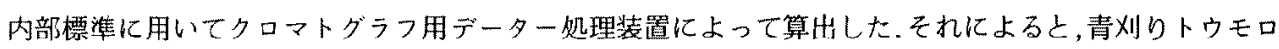

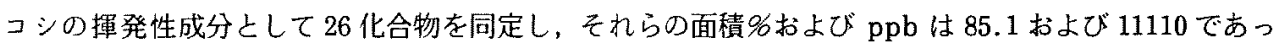
た. 青刈りトゥモロコシの揮発性成分は酸類とアルコール類が多く，4一キセン酸，シスー3-へキセ， ール, ベンジルアルコールが主要な成分であった。一方牛乳の揮発性成分として 40 化合物を同定し, それらの面皘\%および ppbは 81.7 おび 147.6 であった。牛乳の揮発性成分は青刈トゥモロコシの 揮発性成分に比べ量的に非常に少なかった。 また牛乳の揮発性成分は酸類とエステル類が多く，カプリ ル酸，カプロン酸，酢酸エチル，ギ酸エチル，カプリン酸が主要な成分であった．青刚りトウモロコシ に見いだした炭素数 6 のアルコール類が消失して，岸素数 5 のアルコール類が牛乳中に検出された．低 級ヶトン類拉よび酢酸エチルは，青刈りトゥモロコシにも牧にも見いだされた。カルボニル化合物は， 牛乳中に痕跡程度観察された。

日音会報， $57(11) ： 902-906,1986$
\end{abstract}

新鮮な牛乳には特徴的な嗅覚特性があるが，あとあと そのフレーバーは非常に弱い. そ扎ええ, 採食した飼料 によって，牛乳の異常フレーバーの原因になるてとが古 くから認的られている ${ }^{1,2)}$ 。しかしながら飼料作物之牛 乳フレーバーとの関保についての化学的研究は，おまり 行なわ机ていない，そこで手初めとして，青刈り卜ウモ ロコシとそれを給与して飼䖭した乳牛が生産した垺乳の 揮発性成分を分析し，比較検討を行なった。

\section{材料およひ方法}

\section{1. 供試牛と飼料}

本学部附属農場のホルスタイン種乳牛 1 頭 (No. 63 パレード，昭和 58 年 1 月 26 日生，昭和 60 年 2 月 24 日 分婏）を牛舎婂入れて，昭和 60 年 8 月 19 日から 8 月 25 日まで青刚りトウモロコシを自由採食させた。

青刚りトウモロコシ（パイオニアデントP 3424）は その黄熟期に地上部を鎌で刈り取り，押切りで細切して 給与した. 1 日に 30〜 40 kg の青刈りトウモロコシを採 食し, 1 日 $10 \mathrm{~kg}$ 内外老泌乳した。

2.青刈りトウモロコシの溶媒抽出

日畜会報，57（11）：902-906
細切した青刈りトウモロコシ $3 \mathrm{~kg}$ にペンタン・エチ ルエーテルの等量混合溶媒（以下混合溶媒と略す） $9 l$ を加えて， $3^{\circ} \mathrm{C}$ の伶蔵庫に保存した。時々擋拌しなからら 2 週間後滤紙て滤過，濾液を無水硫酸ナトリウムで脱水後 ウイッドマー分留管を使用して濃縮し，暗緑色をした抽 出物を得た。

\section{3. 牛乳の溶媒抽出}

昭和 60 年 8 月 26 日に供試牛の朝乳 $7 \mathrm{~kg}$ (乳脂率 $3.4 \%$, 甘くマイルドな風味がした）を, 東京理化器械 製の上下動式液々向流抽出装置を使用して混合溶媒で抽 出した。 その時の牛乳流量は約 $1.5 \mathrm{l} / \mathrm{hour,}$ 混合溶媒 流量は約 1.2 l/hour であった. 抽出液は脱水後ウイッ ドマー分留管で濃綰し，黄色粘穚な抽出物を得た。

\section{4. 各溶媒抽出物の減圧蒸留}

青刈りトウモロコシおよび牛乳の各溶媒抽出物は，蒸 留水老加えてセミ・ミクロ減圧蒸留装置で数回減圧蒸留し た.その時のクライゼン温度は $30^{\circ} \mathrm{C}$ 以下,減圧度は 30〜 $35 \mathrm{mmHg}$ であった。留出液は氷杖びドライアイス冷却 トラップに捕集し, 塩化ナトリウムで飽和後混合溶媒で 抽出した。抽出液は脱水後ヴィグリュー分留管で濃縮し， 
それぞれ淡黄色および黄褐色の液体を得た。

\section{5. 揮発性成分の分析}

各減圧蒸留物は，まずガスクロマトグラフ・マススペ クトロメーター装置によって分析した (GC-MS)。そ のガスクロマトグラフは 5790 Hewlette Packard で, カラムは Carbowax $20 \mathrm{M}$ の内径 $0.2 \mathrm{~mm}$, 長さ 25 $\mathrm{m}$ のキャピラリーカラムを使用し，力ラム温度は 60 か ら $200^{\circ} \mathrm{C}$ まで $3^{\circ} \mathrm{C} / \mathrm{min}$ で昇温した。キャリャーガスと して、ヘリウムを $1 \mathrm{~m} l / \mathrm{min}$ で流した。 マススペクト ロメーターは JEOL JMS DX-3000で，イオン化電圧 $70 \mathrm{eV}$ ，イオン源温度 $250^{\circ} \mathrm{C}$ ，イオン加速電圧 $3 \mathrm{kV}$ で 操作した。つぎにガスクロマトグラフ装置で分析した (GC). 水素炎イオン化検出器の Shimadzu GC-7A を使用し，カラムは Thermon 3000 (5\%) /Chromosorb W（80〜100メッシュ，AW-DMCS）を充填した 内径 $3 \mathrm{~mm}$ ，長さ $3 \mathrm{~m}$ のU 字ガラスカラムを用い， カラム温度は 50 から $250^{\circ} \mathrm{C}$ まで $4^{\circ} \mathrm{C} / \mathrm{min}$ で昇温した。 キャリヤーガスとして窒素を $40 \mathrm{ml} / \mathrm{min}$ で流し, 注入 口温度は $280^{\circ} \mathrm{C}$ であった。

6. 各成分の面積\%および $\mathrm{ppb}$ 分析

揮発性成分の定量分析は GC と同じ条件で行ない， 各成分の面積 6 は Shimadzu chromatopac C-RIB で測定した。一方内部標㔼にへプタデカンを注入し，そ の既知重量之面積\%から各成分の重量を求め，つぎに試 料 $1 \mathrm{~kg}$ 当りの減圧蒸留物之 $\mathrm{GC}$ 注入量上の容量割合 から，各成分の $\mathrm{ppb}$ 濃度を算出した。

\section{結果およひ考察}

1. 青刈りトウモロコシの揮発性成分

青刈りトウモロコシを直接溶媒抽出し，つぎに減圧蒸 留し溶媒で抽出した抽出物は，GC-MS つぎに GC 分 析を行なった，GC-MS は，標品マススペクトルおよ び既知マススペクトル゙との比較によって，GC は，既 知物質とのリテンションタイムの一致によって成分を同 定した。また各成分の面積\%および ppbは，内部標準 を使用して GC 用データ一処理装置によって算出しだ。 それらの結果を表 1 亿示す.それによると酸類は 9 種類， アルコール類は 8 種類, アルデヒド類は 4 種類, ケトン 類は 2 種類, フェノール類は 2 種類, エステル類は 1 種類 の計 26 化合物を同定した。また面積\%および ppbは，

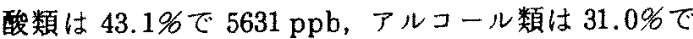

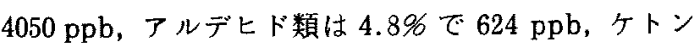

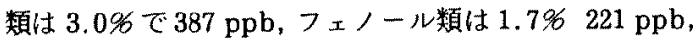

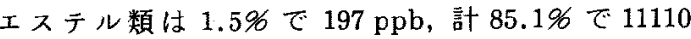
$\mathrm{ppb}$ であっだ，青刈りトウモロコシの揮發性成分は酸
Table 1. Volatile constituents of soiling dent corn

\begin{tabular}{|c|c|c|c|}
\hline Compound & $\begin{array}{l}\text { Peak*1 } \\
\text { No. }\end{array}$ & $\underset{96}{\operatorname{Area}}{ }^{* 2}$ & $\mathrm{ppb}^{* 2}$ \\
\hline \multicolumn{4}{|l|}{ Acids } \\
\hline Acetic acid & 20 & 2.46 & 322 \\
\hline Isobutyric acid & 23 & 0.13 & 17 \\
\hline Butyric acid & 25 & 1.85 & 242 \\
\hline Isovaleric acid & 27 & 1.24 & 162 \\
\hline Caproic acid & 30 & 4.94 & 646 \\
\hline 4-Hexenoic acid & 33 & 31.60 & 4133 \\
\hline Caprylic acid & 36 & 0.55 & 72 \\
\hline Capric acid & 39 & 0.25 & 33 \\
\hline Benzoic acid & 41 & 0.03 & 4 \\
\hline \multicolumn{4}{|l|}{ Alcohols } \\
\hline Ethanol & 4 & 0.18 & 24 \\
\hline 2-Methyl-3-buten-2-ol & 7 & 2.64 & 345 \\
\hline 3-Penten-2-ol & 11 & 3.09 & 404 \\
\hline 1-Pentanol & 14 & 0.39 & 51 \\
\hline 4-Methyl-1-pentanol & 15 & 1.95 & 255 \\
\hline$c i s-3-H e x e n-1-o l$ & 18 & 10.70 & 1399 \\
\hline Benzyl alcohol & 31 & 8.98 & 1174 \\
\hline 2-Phenylethanol & 32 & 3.04 & 398 \\
\hline \multicolumn{4}{|l|}{ Aldehydes } \\
\hline 1-Hexanal & 8 & 1.36 & 178 \\
\hline trans $-2-$ Hexen-1-al & 13 & 2.05 & 268 \\
\hline Benzaldehyde & 22 & 0.20 & 26 \\
\hline Phenylacetaldehyde & 26 & 1.16 & 152 \\
\hline \multicolumn{4}{|l|}{ Ketones } \\
\hline 3-Buten-2-one & 5 & 1.10 & 144 \\
\hline $\begin{array}{l}\text { 3-Methyl-3-buten-2-one } \\
\text { Phenols }\end{array}$ & 6 & 1.86 & 243 \\
\hline Phenol & 34 & 0.72 & 94 \\
\hline Eugenol & 38 & 0.97 & 127 \\
\hline \multicolumn{4}{|l|}{ Esters } \\
\hline Ethyl acetate & 3 & 1.51 & 197 \\
\hline
\end{tabular}

*1 Peak numbers were given in the order of appearance in the programmed temperature GC.

*2 Area percentages and parts per billion concentrations were calculated on a data processor for GC using $n$-heptadecane as the internal standard.

類とアルコール類が多く，また化合物の中，4-へキセン 酸が最む多く含末れ，つぎにシスー3ーへキセノール，ベ ンジルアルコールが多く，乙れら 3 成分で全体の 51.3 \%，6706 ppb 老占めていた。4一キセン酸はトマトか らあ検出されている文. 酢酸 (ピーク番号 20）より前に, 炭素数 5 と 6 のアルコール類およびカルボニル化合物が 
Table 2. Volatile constituents of cow's milk

\begin{tabular}{|c|c|c|c|}
\hline Compound & $\begin{array}{l}\text { Peak*1 } \\
\text { No. }\end{array}$ & ${ }_{\mathscr{\%}} \operatorname{Area}^{* 2}$ & $\mathrm{ppb}^{* 2}$ \\
\hline \multicolumn{4}{|l|}{ Acids } \\
\hline Acetic acid & 26 & 0.05 & 0.09 \\
\hline Butyric acid & 32 & 0.57 & 1.03 \\
\hline Valeric acid & 37 & 0.06 & 0.11 \\
\hline Caproic acid & 42 & 16.66 & 30.19 \\
\hline 2-Ethylhexanoic acid & 46 & 1.36 & 2.47 \\
\hline Caprylic acid & 50 & 22.47 & 40.72 \\
\hline Pelargonic acid & 52 & 0.14 & 0.25 \\
\hline Capric acid & 55 & 6.39 & 11.57 \\
\hline Hendecanoic acid & 57 & 0.02 & 0.04 \\
\hline Lauric acid & 59 & 1.04 & 1.88 \\
\hline Myristic acid & 63 & 0.80 & 1.45 \\
\hline \multicolumn{4}{|l|}{ Hydrocarbons } \\
\hline$n$-Decane & 9 & 0.31 & 0.56 \\
\hline Toluene & 10 & 1.46 & 2.64 \\
\hline$p$-Xylene & 14 & 0.52 & 0.95 \\
\hline$m$-Xylene & 15 & 0.40 & 0.72 \\
\hline o-Xylene & 17 & 1.22 & 2.22 \\
\hline$n$-Butylbenzene & 22 & 0.99 & 1.79 \\
\hline$n$-Pentadecane & 30 & 0.08 & 0.14 \\
\hline$n$-Hexadecane & 33 & Trace & - \\
\hline \multicolumn{4}{|l|}{ Alcohols } \\
\hline Ethanol & 4 & 0.85 & 1.53 \\
\hline 3-Pentanol & 12 & 0.13 & 0.24 \\
\hline 2-Pentanol & 13 & 0.33 & 0.60 \\
\hline 3-Penten-2-ol & 16 & 0.20 & 0.36 \\
\hline 2-Ethylhexanol & 28 & 1.79 & 3.24 \\
\hline Benzyl alcohol & 43 & 0.09 & 0.16 \\
\hline \multicolumn{4}{|l|}{ Aldehydes } \\
\hline trans-2-Hexen-1-al & 18 & 0.08 & 0.14 \\
\hline 1-Nonanal & 25 & 0.07 & 0.13 \\
\hline Furfural & 27 & 0.39 & 0.70 \\
\hline Benzaldehyde & 29 & 0.16 & 0.28 \\
\hline $\begin{array}{l}\text { 5-Hydroxymethyl } \\
\text { furfural }\end{array}$ & 58 & 0.18 & 0.32 \\
\hline \multicolumn{4}{|l|}{ Ketones } \\
\hline 3-Buten-2-one & 5 & Trace & - \\
\hline 3-Methyl-3-buten-2-one & 6 & 0.28 & 0.51 \\
\hline 2-Hexanone & 11 & 0.04 & 0.07 \\
\hline 2-Nonanone & 24 & 0.03 & 0.05 \\
\hline \multicolumn{4}{|l|}{ Esters } \\
\hline Ethyl formate & 2 & 7.49 & 13.57 \\
\hline Ethyl acetate & 3 & 11.13 & 20.16 \\
\hline Dimethyl maleate & 34 & 0.44 & 0.80 \\
\hline Phenols & & & \\
\hline
\end{tabular}

\begin{tabular}{lccr}
$\begin{array}{l}\text { Phenol } \\
\text { Lactones }\end{array}$ & 48 & 2.95 & 5.35 \\
$\begin{array}{l}\delta \text {-Decalactone } \\
\begin{array}{l}\text { Sulfur compounds } \\
\text { Benzothiazole }\end{array}\end{array}$ & 54 & 0.34 & 0.62 \\
& 47 & Trace & - \\
\hline
\end{tabular}

$* 1$ and ${ }^{* 2}$ see Table 1 .

多数同定された．とれらの低沸点成分が，青刈りトウモ ロコシの特徴的なアローマをかもし出すものと思われる。 特に炭素数 6 の不飽和アルコールおよび不飽和アルデヒ ドは，青刘りトウモロコシのグリーンノートへ大いに寄 与している゙

\section{2. 牛乳の揮発性成分}

青刘りトウモロコシで7日間飼趧した乳牛からの牛乳 は，液々向流抽出装置で溶媒抽出し，つぎに減圧蒸留し て抽出物老得た。それを前述と同様 GC-MSつきに GC 分析をして成分を同定し, 各成分の面皘\%扢よび ppb あ前述と同様に算出した。 それらの結果を表 2 に示す。 それによると酸類は 11 種類, 炭化水素類は 8 種類, ア ルコール類は 6 種類，アルデヒド類は 5 種類，ケトン類 は 4 種類，エステル類は 3 種類，フェノール類は 1 種類， ラクトン類は 1 種類，硫黄化合物は 1 種類の計 40 化合 物を同定した。また面積\%および \%で $89.8 \mathrm{ppb}$ ，炭化水素類は $5.0 \%$ て $9.0 \mathrm{ppb，アル}$

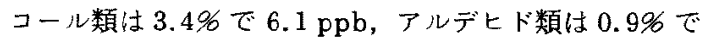

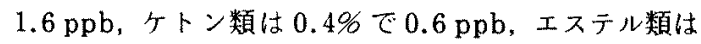
$19.1 \%$ で $34.5 \mathrm{ppb}$, フェノール類は $3.0 \%$ で $5.4 \mathrm{ppb}$, ラクトン類は 0.38 で $0.6 \mathrm{ppb}$, 硫黄化合物は痕跡程度, 計 $81.7 \%$ で $147.6 \mathrm{ppb}$ であった。牛乳の揮発性成分は, 青刈りトウモロコシの揮発性成分に比べ量的に非常に少 ないことがわかった（約1/75の濃度）。また牛乳の揮発 性成分は酸類上エステル類が多く，化合物の中カプリル 酸が最も多く含まれ，つぎにカプロン酸，酢酸エチル， ギ酸エチル，カプリン酸が多く，乙れら5成分で全体の 64.196.116.2 ppb を占めていた。酢酸（ピーク番号 26） より前に, 炭素数 5 のアルコール類, カルボニル化合物, エステル類および炭化水素類が多数同定された。 HONKANEN ら ${ }^{6}$ は既知化合物を乳牛に投与しての動物 実験において，奇数炭素のアルコール類，低級ケトン類 捛よびエチルエステル類が牛乳によく移行し，アルデヒ

ド類，不飽和アルコール扰よび高級ケトン類はほんの痕 跡移行したと報告している。青刈りトウモロコシ中の cis-3-hexen-1-ol および4-methyl-1-pentanol が消 失して，炭素数 5 のアルコール類が牛乳中に検出された とと, 青刘りトウモロコシ中の 3-buten-2-one, 3methyl-3-buten-2-one 拉よび ethyl acetate が微量 


\section{牛乳の揮発性成分}

ではあるが牛乳中にも見出されたこと，カルボニル化合 物が痕跡程度牛乳中に観察されたこと，は彼らの結果と 一致する。また SCANLANら ら は生牛乳と加熱牛乳之の 揮発性成分の比較において，炭素数 3，4，5，7，9のメ チルケトン類, 炭素数 10,12 の $\delta$-ラクトン類, 一キサ ナール, ベンズアルデヒド, 炭素数 $6,8,10$ の酸類, エタノール, ジアセチル，酢酸エチル，パルミチン酸メ チル，その他 3 種の計 19 化合物を生牛乳加ら同定して いる. われわれの結果に比べてカルボニル化合物が成分 的にかなり異なり, 酸類, 了ルコール類, 炭化水素類か 非常に少ない。乙㣗らの違いが，飼料の青刈りトウモロ コシと何らかの関係があるのではないかと思われる、ま た液々向流抽出装置を使用しての牛乳の揮発性成分の分 析も，ての研究が初めてである. 今までの真空蒸留法に 比べて適切であるかどうかも今後の研究で検討したい。

\section{謝 辞}

本研究の実施に当り，で協力いただいた生物生産学部 附属農場の方々に深く感謝します。な打本研究経費の一 部は, 昭和 59 年度文部省科学研究費補助金 (No.
59560275）によった。

\section{文献}

1) ВАвСоск, C.J., J. Dairy Sci., $21: 661-668$. 1938.

2) Petersen, W.E. and J.G. Brereton, J. Dairy Sci., 25: 381-387. 1942.

3) Stenhagen, E., S. Abrahamsson and P.W. McLafferty, in Atlas of Mass Spectra Data Vol. I, II and III. Interscience. New York. 1969.

4) Van Straten, S. and H. MaArse, Volatile Compounds in Food, Qualitative Data, 1 : Index 40. 1983.

5）奥田 治, 香料化学総覧〔 II 〕第 1 版. 502-504. 742-743. 広川書店. 東京. 1968.

6) Honkanen, E., P. Karvonen and A. I. Virtanen, Acta Chem. Scand., $18: 612-618$. 1964.

7) Scanlan, R.A., R.C. Lindsay, L. M. LibBey and E.A. DAY, J. Dairy Sci., 51: 1001-1007. 1968. 


\title{
Volatile Constituents of the Milk of \\ Cow fed with Soiling Dent Corn
}

\author{
Takayasu KAMI and Kazuhiko OHSAKI* \\ Faculty of Applied Biological Science, \\ Hiroshima University, Fukuyama-shi 720 \\ *Inabata Koryo Co., LTD., Osaka-shi 532
}

In order to elucidate the connection between the aromas of forage crops and the flavors of cow's milk, the volatile constituents of soiling dent corn and of the milk of cow fed with soiling dent corn were analyzed via a combined gas chromatograph-mass spectrometer and FID-gas chromatograph (GC-MS and GC). The area percentage and the parts per billion ( $\mathrm{ppb}$ ) concentration of each compound were also calculated on a data processor for GC using $n$-heptadecane as the internal standard. As a result, 26 compounds were identified from the volatile constituents of soiling dent corn, and their area percentages and ppb values were 85.1 and 11110 , respectively. The volatile constituents of soiling dent corn were relatively rich in acids and alcohols, and of these compounds, 4-hexenoic acid, cis-3-hexen-1-ol and benzyl alcohol were the major constituents. On the other hand, 40 compounds were identified from the volatile constituents of cow's milk, and their area percentages and ppb values were 81.7 and 147.6, respectively. Quantitatively speaking, the volatile constituents of cow's milk were very few compared with the volatile constituents of soiling dent corn. The volatile constituents of cow's milk were relatively rich in acids and esters, and of these compounds, caprylic acid, caproic acid, ethyl acetate, ethyl formate and capric acid were the major constituents. Alcohols of a 6 carbon-number found in soiling dent corn disappeared in cow's milk, while alcohols of a 5 carbon-number were detected in the milk. Lower ketones and ethyl acetate were found in both soiling dent corn and cow's milk. Carbonyl compounds were observed in cow's milk only in trace amounts.

Jpn. J. Zootech. Sci., $57(11): 902-906,1986$

Key words: volatile constituents, cow's milk, soiling dent corn, solvent extraction, GC-MS 